Cattaneo, Maria Alejandra; Wolter, Stefan C.

\title{
Migration policy can boost PISA results - Findings from a natural experiment
}

Aarau : SKBF 2012, 22 S. - (SKBF Staff Paper; 7)

口卄f Quellenangabe/ Reference:

Cattaneo, Maria Alejandra; Wolter, Stefan C.: Migration policy can boost PISA results - Findings from a natural experiment. Aarau : SKBF 2012, 22 S. - (SKBF Staff Paper; 7) - URN:

urn:nbn:de:0111-opus-53719 - DOI: 10.25656/01:5371

https://nbn-resolving.org/urn:nbn:de:0111-opus-53719

https://doi.org/10.25656/01:5371

in Kooperation mit / in cooperation with:

\section{SKBF $\mid$ CSRE}

http://www.skbf-csre.ch

\section{Nutzungsbedingungen}

Gewährt wird ein nicht exklusives, nicht übertragbares, persönliches und beschränktes Recht auf Nutzung dieses Dokuments. Dieses Dokument ist ausschließlich für den persönlichen, nicht-kommerziellen Gebrauch bestimmt. Die Nutzung stellt keine Übertragung des Eigentumsrechts an diesem Dokument dar und gilt vorbehaltlich der folgenden Einschränkungen: Auf sämtlichen Kopien dieses Dokuments müssen alle Urheberrechtshinweise und sonstigen Hinweise auf gesetzlichen Schutz beibehalten werden. Sie dürfen dieses Dokument nicht in irgendeiner Weise abändern, noch dürfen Sie dieses Dokument für öffentliche oder kommerzielle Zwecke vervielfältigen, öffentlich ausstellen, aufführen, vertreiben oder anderweitig nutzen.

Mit der Verwendung dieses Dokuments erkennen Sie die Nutzungsbedingungen an.

\section{Kontakt / Contact:}

DeDOCS

DIPF | Leibniz-Institut für Bildungsforschung und Bildungsinformation Informationszentrum (IZ) Bildung

E-Mail: pedocs@dipf.de

Internet: www.pedocs.de

\section{Terms of use}

We grant a non-exclusive, non-transferable, individual and limited right to using this document.

This document is solely intended for your personal, non-commercial use. Use of this document does not include any transfer of property rights and it is conditional to the following limitations: All of the copies of this documents must retain all copyright information and other information regarding legal protection. You are not allowed to alter this document in any way, to copy it for public or commercial purposes, to exhibit the document in public, to perform, distribute or otherwise use the document in public.

By using this particular document, you accept the above-stated conditions of use. 


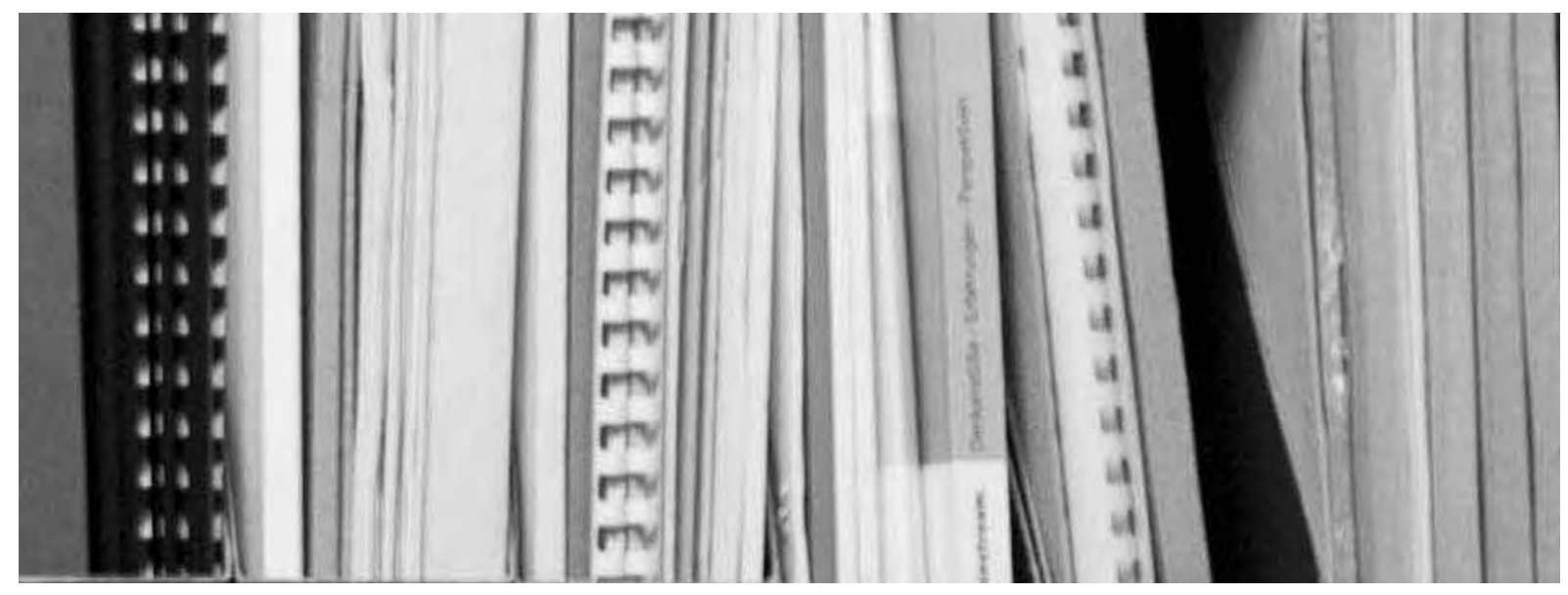

\title{
Migration Policy Can Boost PISA Results -
} Findings from a Natural Experiment

\author{
Maria Alejandra Cattaneo and Stefan C. Wolter
}

SKBF Staff Paper 7

\section{SKBF | CSRE}

Schweizerische Koordinationsstelle für Bildungsforschung

Centre suisse de coordination pour

la recherche en éducation

Centro svizzero di coordinamento

della ricerca educativa

Swiss Coordination Centre for

Research in Education 



\title{
Migration Policy Can Boost PISA Results - Findings from a Natural Experiment
}

\author{
Maria Alejandra Cattaneo* and Stefan C. Wolter** \\ *Swiss Coordination Centre for Research in Education \\ ** Swiss Coordination Centre for Research in Education, University of Bern, CESifo \& IZA
}

\begin{abstract}
Switzerland radically changed its migration policy in the mid-nineties from a «non-qualified only» policy to one that favors the immigration of highly qualified migrants. To analyze the impact of this change on the schooling outcomes of migrants, this paper compares the PISA (OECD Programme for International Student Assessment) results from 2000, which were not yet affected by the change in the migration policy, with the PISA 2009 test. Using a Blinder-Oaxaca decomposition analysis, we find that almost $70 \%$ of the 43 -point increase (more than one standardized school year) in the PISA scores of first-generation immigrant students in an environment with stagnant Swiss PISA results was due to changes in the individual background characteristics of the new immigrants (direct effect) and improved school composition (lower shares of students who did not speak the testing languages as an indirect effect). The indirect effects also indicate that internationally comparative analyses should more fully consider differences in national migration policies when assessing the success of migrant integration.
\end{abstract}

JEL-Codes: I21, I24, J15

Key-words: Blinder-Oaxaca decomposition, migration, natural experiment, PISA

Communicating author: Maria A. Cattaneo, Swiss Coordination Centre for Research in Education (SKBF), Entfelderstrasse 61, CH-5000 Aarau, maria.cattaneo@skbf-csre.ch 
This Paper is also published as IZA Discussion Paper (www.iza.org)

Aarau, January 2012

(C) SKBF-CSRE 


\section{Introduction}

A decade of internationally comparative analyses of schooling outcomes using data from the Program for International Student Assessment (PISA) (see Hanushek $\mathbb{\&}$ Wössmann, 2011) has consistently shown that in almost all participating countries, students with a migrant background achieve significantly lower test results than native students. While in many countries even second-generation immigrant students have lower test scores than comparable native students, some countries such as Canada and Australia have managed to integrate immigrant students well, and their test results are comparable to those of natives, even for first-generation immigrants. However, PISA participating countries also differ considerably with regard to their immigration policies, which can either ease or hinder the integration of immigrants in the host society. Although most analyses account for the individual socio-economic backgrounds of students when comparing immigrants and natives, the extent to which these analyses account for the more complex effects that immigration policies may exert on schooling outcomes via changes in school composition (peer effects, threshold effects, and other factors) is unclear. Furthermore, even if one were to control for all of this, it is still difficult to interpret differences in migration policies resulting from a cross-sectional analysis as being exogenous and, consequently, to interpret a correlation with the relative schooling outcomes of migrants as being causal.

Therefore, this paper attempts to shed new light on the question of the impact of migration policy on the schooling outcomes of immigrant students using a radical change in immigration policy in Switzerland in the mid-nineties as a natural experiment. Until 1994, Switzerland had a "low-qualified only" policy that not only favored the immigration of low-skilled immigrants but also made it very difficult for qualified migrants to enter Switzerland. After 1994, with the so-called Three Circles Policy Switzerland implemented a more or less a free movement of labor for citizens of the European Economic Area (EEA) and barred entry for non-qualified migrants from all other countries. This change has led - as was expected - to a radical change in the mix of qualifications of new immigrants to Switzerland.

Using the PISA test scores from the years 2000 and 2009, we can now analyze the impact of different migration policy regimes on the schooling outcomes of migrants by comparing the results of first-generation immigrant children, whose parents were not affected by the new immigration laws (using student results from PISA 2000), with the results for 15-year-old immigrant students whose parents had entered Switzerland after the new policy had been implemented (using the 2009 PISA results). The comparability of the two PISA tests in 2000 and 2009 is enhanced because the test results of native Swiss students remained almost unchanged between the two points in time. Furthermore, to separate the effects that are due to the change in migration policy from the effects that are due to improvements in immigrant integration policy, we compare the changes in the PISA test scores of first-generation immigrants with the changes in PISA scores for similar second-generation immigrants (children born in Switzerland of two foreign born parents) over time. The descriptive evidence shows that the impact of the change in migration laws $(+43$ points in PISA scores) dwarfs any potential integration effect ( +14 points in PISA scores for second-generation immigrant students) that may have occurred over the last decade.

Using a Blinder-Oaxaca decomposition analysis, we show that some $48 \%$ of the improvement in the PISA scores of first-generation immigrants is directly due to changes in their individual socio-economic background characteristics, whereas an additional $20 \%$ of the improvement is due to the changes in school composition induced by the new immigration policy.

The paper is organized as follows: Section 2 briefly describes the history of Swiss immigration policy. Section 3 provides a brief review of the literature on migrants and schooling. Section 4 presents the data and some descriptive evidence. Section 5 documents the empirical findings and results, and Section 6 concludes the paper. 


\section{A brief history of Swiss immigration policies}

By the end of the 19th Century, Switzerland had definitively made the transition from an emigration country into a net immigration country. The period before the First World War was characterized by complete freedom of movement and residence and the relatively easy acquisition of a Swiss citizenship. After the First World War ended, this laissez-faire attitude towards immigrants changed, and in 1925, the federal government adopted the responsibility of regulating settlement conditions for foreigners. ${ }^{1}$

The economic growth after the Second World War increased the demand for foreign workers. The immigration policy during this period was based on two principles: first, the foreign-born labor force should be used to counteract economic cycles, and therefore residence should be limited to a short period (seasonal work permits that could only be turned into permanent residence after ten and later five years of work in Switzerland). Second, immigrants should only be employed in jobs for which the resident population showed no interest, and therefore migrants were almost exclusively low-qualified and mainly employed in a few sectors of the economy (construction, agriculture and the machines and the textile industry). To make the recruitment of migrant workers more efficient, Switzerland established treaties, first with Italy, then with Spain and later with Portugal, and granted those countries exclusive rights to send workers to Switzerland. Because of the booming economies in Switzerland and Southern Europe, the immigrant population became more diversified, and by the eighties, what was then the Socialist Republic of Yugoslavia became the main sending country.

In the nineties, after five years of economic stagnation and a major industrial restructuring, the demand for low skilled migrants declined significantly, and a large share of the now resident, low qualified migrant population had difficulty finding jobs. At the same time, the expanding new service and high-tech industries complained about the difficulties that they faced in recruiting specialists from abroad under the then current migration regime. Developments in the European Union (the free movement of labor) led to a radical change in Swiss migration policy in 1994 with the introduction of the so-called Three Circles Model. Under this model, citizens of the European Economic Area (EEA) were included in the first circle and given priority for work permits. The second circle included people from the United States, Canada, Australia and New Zealand, who could be recruited for certain jobs if no applicant could be found within the EEA. The third circle encompassed all other countries, from which it became almost impossible to migrate to Switzerland for work. Due to complaints about the discriminatory nature of this model, the Three Circle Model was replaced by the Two Circle Model in 1998. In this model, the first circle encompassed citizens of the EEA, and the second circle included the rest of the world. In 2002, the first bilateral treaties between Switzerland and the European Union (EU) granted the free movement of labor to all citizens of the EEA (first circle), and immigration for qualified jobs from countries belonging to the second circle was only permitted with the condition that such labor could neither be found in Switzerland nor the EEA.

With the economic recovery at the end of the nineties, the change in the immigration policy began to have a lasting and profound impact on both the qualifications of the new migrants as well as their countries of origin. Whereas before the change, the majority of new migrants did not speak any one of the national languages and had no post-compulsory education, by the turn of the century nearly half of the new migrants had an academic degree, and a third spoke one of the national languages. ${ }^{2}$

This change in immigration patterns is also clearly reflected in the change in the composition of the school populations that were tested in the first round of PISA in 2000 and the fourth round in 2009.

For a detailed description of the Swiss immigration policy, see Piguet (2006) and Wicker et al. (2003)

The largest share of the new immigrants now comes from neighboring Germany and France. 


\section{Migrants and school performance}

The general consensus in the literature, especially regarding studies using PISA data, is that immigrant students have lower educational achievement than students from the resident population (Ammermüller, 2007; OECD, 2006; OECD, 2010), and this difference is mainly due to differences in parental education, occupation, income and (especially in non-English speaking countries) because the test language is not always the migrants' first language, they have a lower proficiency in the test language (e.g. Entorf \& Minoui, 2005; Entorf \& Tatsi, 2009; Jungbauer \& Gross, 2011; OECD, 2006; OECD, 2010; Rangvid, 2005, and Schneeweis, 2011). Meunier (2011) in a study of PISA 2000 data, using the Juhn, Murphy and Pierce decomposition, finds that compositional differences in parental background can explain up to $90 \%$ of the score difference between Swiss and second generation immigrants and $80 \%$ of the score difference between Swiss and first generation immigrants.

Most of the literature focuses on the differences in outcomes between immigrant and native students, and considers the immigrants as single group. However, the composition of the immigrant group can be quite heterogeneous. The immigrant group may be composed of students from highly educated and wealthy parents as well as of parents with poor educational, cultural and social backgrounds. An indication of the need to be aware of the heterogeneous composition of the migrant population within a country is that the socioeconomic heterogeneity of immigrants in most OECD countries is significantly higher than that of the native population (see also Schnepf, 2008).

The size of the difference in schooling results between immigrant and native students is highly dependent on the country being studied. An OECD (2003) analysis of the PISA 2003 test results showed that these differences were the most pronounced in Austria, Belgium, Denmark, France, Germany, the Netherlands and Switzerland, and the performance differences were less pronounced in Australia, Canada and New Zealand. Some of the differences in the success of migrants in schools relative to native students disappear for some countries once we make the analysis conditional on family background characteristics (Dustmann et al., 2011), and in some countries the migrant-native difference disappears once we focus solely on second generation immigrants (Song $\mathbb{\&}$ Robert, 2010). However, the industrialized countries nonetheless continue to differ considerably in the share of migrants, the socio-economic background of migrants relative to the native population and the success of integration across different generations of migrants.

In addition to differences in socio-economic endowment, residential segregation and school system characteristics such as tracking (Entorf $\&$ Lauk, 2006; Cobb-Clark et al., 2011) tend to widen the differences in schooling outcomes between migrants and natives. Multiple studies (e.g. Brunello $\mathbb{\&}$ Rocco, 2011; Coradi Vellacott et al., 2003; Entorf \& Tatsi, 2009; Jensen \& Rasmussen, 2008; Rangvid, 2007, and Sund, 2009) find that high shares of migrant students in schools (which is often the result of residential segregation) have a negative impact on the schooling results of all students, but most profoundly for the migrants themselves (see especially Ohinata $\mathbb{B}$ van Ours, 2012) and students from disadvantaged socioeconomic backgrounds.

However, to our knowledge, this is the first study that investigates the impact that a change in migration policy and a consequent change in the characteristics of the immigrant population can have on the school performance of immigrant children.

\section{Data and descriptive statistics}

This study uses data from the first (2000) and fourth (2009) PISA tests, conducted by the Organization for Economic Cooperation and Development (OECD). PISA is a standardized test administered to 15-year-old 
students in OECD member countries and other participating countries who are enrolled in grades seven and above. Students are assessed in three domains: reading, math and science. The sample is drawn using a two-stage stratification design. First, schools within the country are randomly selected. Second, a random sample of students is selected from within each school. In addition to the test results, PISA includes a student questionnaire with family and socio economic background information, ${ }^{3}$ and a school questionnaire with information on school type and school demographics. We will focus on reading skills, which was the primary domain for both the 2000 and 2009 PISA tests. The reading scores have been standardized to have a mean of 500 points and a standard deviation of 100.

In Switzerland, an additional representative sample of students in grade 9, the last year of compulsory education, has been collected for each of the four PISA tests that have been conducted thus far. We use this so-called national sample in our analysis, first because a comparison of students in the same grade is more adequate for our purposes, and, second, because the over-sampling in the national sample increases the number of observations considerably. In the Swiss national sample, 7,997 and 15,844 students were interviewed in 2000 and 2009, respectively, and the PISA average scores in reading for Swiss children were 494 points in 2000 and 501 points in 2009 (OECD, 2011b). ${ }^{4}$

After deleting those observations with missing values that we could not impute, we have a final sample of 6,754 students with an average PISA reading score of 502 points for 2000 , and 13,988 observations and an average score of 509 points for 2009. The average scores are slightly higher (but not statistically significantly so) than the average scores using the full sample with missing background information.

\section{Who is an immigrant?}

One of the most important questions when comparing migrants with natives is the definition of students with migrant backgrounds. PISA does not provide information on citizenship. However, the students have to report information on their country of birth, as well as those of their mother and father. ${ }^{5}$ Based on these three variables, we can construct four different definitions of immigrants. Although the results vary greatly depending on how we define immigrants, as we will show in later sections, this issue has thus far not received enough consideration in the PISA literature.

- Definition 1: At least one parent was born outside Switzerland (broadest definition).

- Definition 2: Both parents were born outside Switzerland, independent of where the child was born or the child was born abroad of at least one foreign born parent. This definition therefore includes both first and second generation immigrants. Depending on where the child was born, we arrive at either definition 3 (first generation immigrant) or definition 4 (second generation immigrant).

- Definition 3: The parents and child were born abroad.

- Definition 4: Child born in Switzerland from two parents born abroad.

3 Missing data is an issue in all PISA tests. For one of the most important variables used in the construction of the socio-economic index (SEI), parents' education, some $5 \%$ of the responses in 2000 and $4 \%$ in 2009 were missing. We replaced the missing values with the full sample averages. To check the sensitivity of our method of imputing missing values, we also predicted the missing values by regressing them on other background characteristics. Because our results did not change qualitatively, we use the averages in this paper. Furthermore, comparing the responses for parents' education with census data, we discovered that the share of parents with no post-compulsory education in the data from the PISA background questionnaire was too high. Therefore, we double-checked the students' information regarding parental education with the information on parental occupation (ISCO classification). In cases of inconsistent data, we imputed the educational level that corresponded to the educational level that was closest to the ISCO level. In so doing, we obtained averages that match the census averages quite closely.

4 The PISA average scores in reading are 497 for 2000 and 502 for 2009 using the national sample of students in grade 9 (EDK, 2011).

5 Technically, because we do not have information on the nationalities of the students but only their places of birth, we could label a native Swiss student an "immigrant» if, for example, his parents are Swiss but were born abroad. Although this contaminates all of the results of studies working with PISA data, we do not think that this is a problem that would substantially quantitatively alter our results. 
Of these four possible definitions, definition 3 (first generation immigrants) is the most important for our purposes, as it is the most immediately affected by changes in migration policies because almost all the children included in this category were born in the year (1994) when the new migration policy was implemented. Because they were born abroad, the possibility that the parents of these individuals had already migrated to Switzerland under the old migration policy can, in almost all cases, be excluded. Conversely, the children in definition 4 were born in Switzerland in the year that the new policy became effective, and therefore it is almost certain that their parents had migrated to Switzerland under the old policy regime.

Table 1 presents average reading scores for the four categories of immigrants compared to natives and differentiated by year. The gap between immigrants and natives is the smallest under definition 1 and 4 . This is not surprising for definition 1 as these children were born in Switzerland and one of their parents was also born in Switzerland (being either Swiss or already well integrated into the host country). The largest gap in scores between immigrants and natives appears (not surprisingly) under definition 3 ( 423 points compared to 511 for 2000 and 466 compared to 513 for 2009). The descriptive data shows that although the PISA scores for each group were better in 2009 than in 2000 , the scores of students in definition 3 showed the largest increase between 2000 and 2009.

Moreover, the higher total score for Switzerland in 2009 seems to be caused mainly by the higher scores obtained by immigrant students, as the score for native children remained more or less constant during the period (using the inverse of either definition 1 or 2 to define natives).

Table 2 shows that for the sample of immigrants, regardless of definition, the proportion of parents with tertiary degrees increased, but mostly for first generation immigrants. The share of parents with college degrees (university degrees in Switzerland) almost doubled, at the expense of the share of parents with no post-compulsory education, which was reduced by almost 50\%. Additionally, the percentage of immigrant children who did not speak the test language declined significantly. These data indicate that the change in migration policy had a notable effect on the socio-demographic composition of new immigrants.

For the following multivariate analysis, we focus on these new immigrants (those who are first generation according to definition 3 ) and use immigrants included in definitions 1 (all children with at least one parent born abroad) and 4 (both parents born abroad but where the child was born in Switzerland) for the purposes of comparison. Concerning definition 3 we can be almost certain that those students who were age 15 in PISA 2000 are the children of parents who immigrated under the old migration policy regime, whereas most but not all of the students tested in 2009 were the children of parents that immigrated under the new policy6. Thus, this seems to be the most relevant definition for our purposes as this is the group of immigrants for which we might expect the greatest impact of the change in migration policy.

\section{Empirical methods and results}

As noted in Section 3, socio-economic characteristics such as parental education or occupation play an important role in explaining the differing performances of immigrant and native children.

We can analyze this issue using our data by estimating the following education production function:

score $_{i}{ }^{j}=\alpha^{j}+\beta^{j} X_{i}^{j}+u_{i}{ }^{j}$

6 This would not be the case for individuals who are the children of immigrants but were born in Switzerland (immigrants under definitions 1 or 4 ). 
Where score $_{i}$ is the PISA reading score for person $\mathrm{i}$ and $\mathrm{j}$ indicates whether an individual is a native or an immigrant. $X$ represents individual characteristics and $u$ is an error term with mean zero and variance $\sigma_{j}^{2}$.

The results, presented in Table 3, show that for both years, 2000 and 2009, PISA scores are positively influenced by higher parental socioeconomic status (SEI), speaking the test language and having more than a hundred books ${ }^{7}$ at home. Employing a Blinder-Oaxaca decomposition (Blinder, 1973; Oaxaca, 1973), we find that approximately $75 \%$ of the score gap between Swiss children and first generation immigrant children can be explained by differences in endowments. This explained percentage is somewhat smaller than that found by Meunier (2011), which was approximately $80 \% .{ }^{8}$ The difference can be explained by the different treatments of the missing values.

After having shown the importance of family background variables in explaining differences in school performance, we proceed to analyze whether the important increase in the PISA scores for first generation immigrations between 2000 and 2009 was also due to an improvement in the individual characteristics of immigrants, in particular an improvement in the socio-economic backgrounds of new immigrant parents, and therefore a consequence of the change in migration policy.

We do this by decomposing the score gap for first generation immigrants between the years 2000 and 2009 into an explained and an unexplained component, again using a Blinder-Oaxaca decomposition. For each year (2000 and 2009), we estimate the following educational production function:

score $_{i}^{t}=\alpha^{t}+\beta^{j} X_{i}^{t}+u_{i}^{t}$

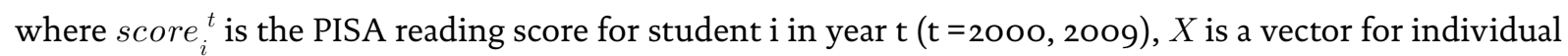
characteristics, such as parents' educational level, parents' socioeconomic index and language spoken at home and $u_{i}^{t}$ is an error term with mean zero and variance $\sigma_{t}^{2}$.

Following Blinder-Oaxaca, we decompose the mean score difference between 2000 and 2009 as follows:

$$
\operatorname{score} \bar{e}_{09}-\operatorname{scor} \bar{e}_{00}=\left(\bar{X}_{09}-\bar{X}_{00}\right) \hat{\beta}_{09}+\bar{X}_{00}\left(\hat{\beta}_{09}-\hat{\beta}_{00}\right)
$$

where the first summand shows how much of the change in PISA scores between 2000 and 2009 can be explained by differences in the predictors or characteristics. This part of the change tells us the extra number of PISA points immigrant students would have had in 2000 if they had had the same observable characteristics as the students in 2009 (the group differences in predictors are weighted by the coefficients from 2009). The second summand shows the contribution of the difference in the coefficients to the total score gap. This is known as the unexplained (or discrimination) component, as it includes the part of the change (or gap in the case of discrimination) that cannot be accounted for by the difference in endowments. In our case, this component could be observed as an upper bound for the impact of improved immigrant integration, given that this proportion shows improved performance on the part of immigrants, regardless of the change in the observable endowments. It is an upper bound of the integration effect because it also includes any potential impact that could stem from a change in the unobservable characteristics of the students.

7 The number of books has proven to be a good proxy for the social and cultural capital of parents, which have significant impacts on the reading skills of pupils (see, e.g., Hanushek $\mathbb{O}$ Wössmann, 2011, p. 116ff).

8 Although Meunier (2011) decomposes the gap using the Juhn, Murphy, Pierce (JMP) method, and we apply the Blinder-Oaxaca method, the results do not vary a great deal between the two decomposition methods. If we analyze second generation immigrants (definition 4) instead of first generation immigrants, our results are very similar to those found by Meunier, showing that between 90 and $95 \%$ of the gap can be explained by different characteristics.

9 We use the coefficients from 2009 as weights. There are several alternatives to this (see Reimers, 1983; Cotton, 1988; Neumarkt, 1988; Oaxaca \& Ransom, 1994). Another possibility would be to calculate a threefold decomposition of the form scor $\bar{e}_{09}-\operatorname{scor} \bar{e}_{00}=\left(\bar{X}_{09}-\bar{X}_{00}\right) \hat{\beta}_{00}+X_{00}\left(\hat{\beta}_{09}-\hat{\beta}_{00}\right)+\left(\bar{X}_{09}-\bar{X}_{00}\right)\left(\hat{\beta}_{09}-\hat{\beta}_{00}\right)$ to avoid making assumptions about which should be used as a weight. In this specification, the last summand shows how much of the gap can be explained by differences in the predictors and the coefficients. 
Panel A in Table 4 provides the estimation results from the OLS regressions for 2000 and 2009. We use the PISA reading score as a dependent variable, and we control for the demographic characteristics of the students such as gender, age and place of residence, family characteristics such as whether the child lives in a single-parent, mixed or nuclear household and whether the child has any siblings. The most important explanatory variables for our purposes are the socio-economic background characteristics of the parents, among which we include the socio-economic index, parents' education, the number of books at home, and the language spoken at home. The results for first generation immigrants are in line with previous results in the literature. The only difference we find is that there is no longer a direct effect of parental education once the socioeconomic index and number of books at home are controlled for. ${ }^{10}$

Panel B of Table 4 shows the decomposition results. The total score gap between 2000 and 2009 is 43 points, of which approximately 17 points (approximately 40 percent) can be explained by differences in observable endowments between the two years. The factors that contribute the most are a higher socioeconomic index, a larger proportion of immigrant students who speak the language of the test at home, a higher number of students from households with more than a hundred books and the larger share of females in 2009. For the $60 \%$ of the difference that cannot be explained by changes in the observable endowments, the most salient factor is the increase in the coefficient for females. ${ }^{11}$

Table 5 presents the estimation results when we include country or region of origin. The results do not change drastically, except for language spoken at home, which becomes insignificant. This is because its effect is absorbed by the coefficients of some of the regions of birth. A significant positive effect on test scores is found for students speaking the test language and coming from Germany, Austria, France or Belgium. The inclusion of these variables increases the explained component of the gap from $40 \%$ to $48 \%$.

\section{School characteristics and peers}

Thus far we have analyzed the impact that the changes in the individual endowments of new immigrants had on increases in PISA test scores, but because it is likely that the new immigrants come from better socio-economic environments, the residential choices of the parents may also allow the students to attend better schools than the average first generation immigrants in the 2000 PISA test. We therefore include school characteristics as explanatory variables in a second step of our education production function, as well as information on peers.

In Table 6 we include school characteristics such as total enrollment, school location, whether the school is financed by public or private funds and the proportion of foreign language speakers in the school. Previous studies (for Switzerland, see Coradi Vellacott et al., $2003^{12}$ ) have shown that the effect of the latter is not linear and that the negative effect of a bigger fraction of students who do not speak the test language on the performance is almost exponential once a threshold of $20 \%$ of these students is crossed. We therefore use three dummy variables: less than $20 \%$, between 20 and $40 \%$ and more than $40 \%$ of students in a school who do not speak the test language. Due to the simultaneity (Manski, 1993) or reflection issue, we can expect that if the performance of other students or peers has an effect on a student's performance, then the performance of that student will also have an effect on the scores achieved by others. As we cannot correct for selection and simultaneity problems given the nature of our data, the coefficients of the school composition variables should not be interpreted as causal. ${ }^{13}$

The proportion of migrant children (first and second generation) who attend schools with more than $40 \%$ foreign language speakers reduced drastically between 2000 and 2009. This was compensated by an in-

10 If we regress PISA score on parental education alone, we find a positive and highly significant effect of tertiary education.

11 The results do not change when we use canton of residence instead of region.

12 Coradi Vellacott et al. (2003) have analyzed the PISA 2000 data for Switzerland using a hierarchical multilevel model with dummy variables for the share of students who do not speak the test language in the second level of their model.

13 For a recent overview on peer effects in education and causality issues, see Sacerdote, 2011. 
crease in the fraction of students attending schools with less than $20 \%$ foreign speakers. This is due probably to the increment of immigrants from neighbor countries, and we expect this to have an effect on the PISA scores (see Table 6).

Results in Table 7 show that it is indeed the higher proportion of other students in school who do not speak the test language that is the primary contribution to low test scores both in 2000 and in 2009 . Because the proportion of students not speaking the test language is much smaller in 2009, this variable explains a great deal of the change in the test scores of first generation immigrants between 2000 and 2009 . The part of the difference explained by observables increases from approximately $48 \%$ to approximately $68 \%$. With respect to other school characteristics attending a private school ${ }^{14}$ has a positive influence on the PISA scores and a larger number of students a negative, but these variables do not contribute to explain the score differences between the two years.

Table 8 shows the decomposition results for the four definitions of immigrants. As shown previously, for definition 3, approximately $48 \%$ of the difference in the score gap between 2000 and 2009 can be explained by differences in individual endowments (not including school and peer characteristics). When considering, for example, the broadest definition of immigrants (definition 1 ), the improvement between 2000 and 2009 is not only half of what can be observed for the first generation immigrants, but the share that can be explained by changes over time in observed individual endowments is also smaller (34\%). This result could have been expected, as the largest shares of migrants under definition 1 are those that have lived in Switzerland for a long time. Therefore, the background characteristics for this group did not change as much as those of the group of first generation immigrants. For immigrants that were born in Switzerland of two foreign-born parents, the increase in PISA scores between 2000 and 2009 is not only the smallest but also cannot be explained by changes in observable endowments at all. ${ }^{15}$

When we include school characteristics, and especially the proportion of foreign language speakers, the explainable component of the score gains over time increases for all definitions of immigrants. This is because the percentage of students who attend schools with more than $40 \%$ students that do not speak the test language was reduced (for all definitions of immigrants), and the percentage of students who attend schools with less than $20 \%$ foreign speakers increased inversely. Although all immigrants benefit from lower shares of students who do not speak the test language in Swiss schools, the first generation immigrants benefit the most. This is because first generation immigrants, despite having much better socio-economic backgrounds on average in 2009, are still the most heterogeneous group of students. The first generation immigrants represent the two extremes of the society, including both those students with the most advantaged backgrounds and those students with the least advantaged ones. Because it is predominantly the lower-achieving students ${ }^{16}$ that benefit from better peers, on average the first-generation immigrants themselves are also those that benefited the most from the improved composition of new immigrants.

14 Contrary to other studies (see, e.g., OECD, 2011a) that show better results for pupils attending public schools, we find a negative effect. The explanation for this difference lies in the use of the national PISA sample instead of the international PISA sample. In the national PISA sample, pupils are compared conditional on enrollment in the 9 th grade, whereas in the international sample, they are compared conditional on being 15 years old. As many pupils attending private schools have repeated school years, they are older on average than the average 9 th grader in a public school, whereas in the international sample, they are more likely to be in the 8 th grade at the age of 15 instead of being in the 9 th grade.

15 Another interpretation of this is that the 13 points of improvement between 2000 and 2009 is the upper bound of the impact of improved integration of students with migrant backgrounds in Swiss schools. The effect size is, however, more than three times smaller than the increase in test scores of first-generation immigrants. Given that the part of the increase for first generation immigrants that cannot be explained by changes in individual endowments and school composition effects is also about 15 PISA points, a comparison of the results for these two groups of immigrant students is a good indication that the upper bound of integration effects is around this number.

16 A number of past studies have shown that peer effects are usually non-linear (see Lavy et al., 2009; Sund, 2009), and low-achieving students are more affected by the presence of better peers. 


\section{Conclusions}

In most OECD countries, migrant children have considerably lower schooling outcomes compared to the native population, although judging from PISA test score differences, some countries seem to perform much better than others. In the past, these inter-country differences have largely been attributed to differences in integration policies and much less to differences in migration policies. Because it is difficult to separate integration and immigration policies in a cross-country analysis, this paper uses a radical change in migration laws in the mid 1990's in Switzerland as a natural experiment to analyze the impact that migration policies can have on the schooling outcomes of migrant children.

Comparing first generation immigrant children's PISA 2000 test scores with first-generation immigrant children in the PISA 2009 test shows a remarkable increase of 43 points in the PISA test score. Two thirds of this increase can be attributed to observable changes in the individual socio-economic characteristics of the new migrants and the positive impact that this also had on school composition by reducing the shares of students who did not speak the test language in many schools below the threshold that negatively impacts student outcomes. The observation that PISA test results for the native population remained stable over the whole decade makes it possible to conclude that the increase in performance cannot be attributed to an overall improvement in schooling in Switzerland. Additionally, at most a third (some 15 PISA points) of the improvement of first-generation immigrant students can be attributed to an improved integration policy. This number is corroborated by the fact that if one compares the increase in test scores with the improvement in second generation immigrant students using a difference-in-difference approach, the increase that cannot be explained by changes in the observable socio-economic characteristics of students over the last decade is also about this size.

Therefore, considering that a change in migration policy was able to improve the PISA results of first-generation immigrant students by almost a third of a standard-deviation in PISA scores over a decade alone, it becomes clear that differences in immigration policies and laws probably explain as much if not more of the differences in the successes of migrants in OECD countries as the differences in policies to integrate migrants into the national school systems. For comparative purposes, it is also important to note that a about a third of the improvement came through indirect effects (changes in school composition) and could therefore not be accounted for when controlling for individual characteristics of migrants alone, which is usually the case when comparing the country-specific schooling outcomes of migrants. 


\section{References}

Ammermüller, A. (2007). Poor Background or Low Returns? Why Immigrant Students in Germany Perform so Poorly in the Programme for International Student Assessment (Education Economics, 15 (2), 215-230)

Blinder, A. S. (1973). Wage discrimination: Reduced form and Structural Estimates (The Journal of Human Resources, $8,436-455)$

Brunello, G. \& Rocco, L. (2011). The Effect of Immigration on the School Performance of Natives: Cross Country Evidence using PISA Test Scores (IZA DP No. 5479)

Cobb-Clark, D. A.; Sinning, M. \& Stillmam, S. (2011). Migrant Youths' Educational Achievement: The Role of Institutions (IZA DP No. 6150)

Coradi Vellacott, M.; Hollenweger, J.; Nicolet, M. \& Wolter, S. (2003). Soziale Integration und Leistungsförderung. Thematischer Bericht der Erhebung PISA 2000. Neuenburg: BFS/EDK

Cotton, J. (1988). On the decomposition of wage differentials (The Review of Economics and Statistics, 70, 236-243)

Dustmann, C., Frattini, T. \& Lanzara, G. (2011). Educational Achievement of Second Generation Immigrants: An International Comparison (Centre for Research and Analysis of Migration CDP, No 16/11)

EDK (2011). PISA 2009: Regionale und kantonale Ergebnisse. Neuchatel: Konsortium PISA

Entorf, H. \& Minoiu, N. (2005). What a Difference Immigration Policy Makes: A Comparison of PISA Scores in Europe and Traditional Countries of Immigration (German Economic Review, 6 (3), 355-376)

Entorf, H. \& Lauk, M. (2008). Peer Effects, Social Multipliers and Migrants at School: An International Comparison, (Journal of Ethnic and Migration Studies, 34 (4), 633-654)

Entorf, H. \& Tatsi, E. (2009). Migrants at School: Educational Inequality and Social Interaction in the UK and Germany (IZA DP No. 4175)

Hanushek, E. A. \& Wössmann, L. (2011), The Economics of International Differences in Educational Achievement, In: E. A. Hanushek, S. Machin, L. Wössmann (Eds.): Handbook of the Economics of Education, Vol. 3, San Diego: North-Holland, 89-200

Jensen, P. \& Würtz Rasmussen, A. (2011). The Effect of Immigrant Concentration in Schools on Native and Immigrant Children's Reading and Math Skills (Economics of Education Review, 30 (6), 1503-1515)

Jungbauer, M. \& Gross, C. (2011), More Private Schools for Nonnative Students? Migrant Performance in Private Schools of Differing National Contexts (Education Research International, Article ID 121250)

Lavy, V.; Silva, O. \& Weinhardt, F. (2009). The Bad, the Good, and the Average: Evidence on the Scale and Nature of Ability Peer Effects in Schools (NBER WP No. 15600)

Manski, C. F. (1993). Identification of Endogenous Social Effects: The Reflection Problem (The Review of Economic Studies, 60 (3), 531-542)

Meunier, M. (2011). Immigration and Student Achievement: Evidence from Switzerland (Economics of Education Review, 30, 16-38)

Neumark, D. (1988). Employers' discriminatory behavior and the estimation of wage discrimination (The Journal of Human Resources, 23, 279-295)

Oaxaca, R. L. (1973). Male-Female Wage Differentials in Urban Labor Markets (International Economic Review, 14 (3), 693-709)

Oaxaca, R. L. \& Ransom, M. R. (1994). On discrimination and the decomposition of wage differentials (Journal of Econometrics, 61, 5-21)

OECD (2006). Where immigrant students succeed. A Comparative Review of Performance and Engagement in PISA 2003. Paris: OECD

OECD (2010). PISA 2009 Results: Overcoming Social Background. Equity in Learning Opportunities and Outcomes. Paris: OECD

OECD (2011a). Private schools: Who benefits? (PISA in Focus, 7)

OECD (2011b). How are school systems adapting to increasing numbers of immigrant students? (PISA in Focus, 11)

Ohinata, A. \& van Ours, J. C. (2012). How Immigrant Children Affect the Academic Achievement of Native Dutch Children (IZA DP No. 6212)

Piguet, E. (2006). Einwanderungsland Schweiz. Fünf Jahrzehnte halb geöffnete Grenzen. Bern: Haupt

Rangvid, B. S. (2007): Sources of Immigrants' Underachievement (Education Economics, 15(3), 293-326)

Reimers, C. W. (1983), Labour market discrimination against Hispanic and Black men (Review of Economics 8 Statistics, 65, 570-579)

Sacerdote, B. (2011). Peer Effects in Education: How might they work, how big are they and how much do we know thus far? In: E. A. Hanushek, S. Machin, L. Wössmann (Eds.): Handbook of the Economics of Education, Vol. 3, San Diego: North-Holland, 249-277

Schneeweis, N. (2011), Educational institutions and the integration of migrants (Journal of Population Economics, 24, 1281-1308) 
Schnepf, S. V. (2008). Inequality of Learning amongst Immigrant Children in Industrialised Countries (IZA DP No. 3337)

Song, S. \& Robert, P. (2010). Immigrant Student Investigation in PISA 2006: A Call for a More Nuanced Examination (Journal for Educational Research Online, 2 (1), 32-52)

Sund, K. (2009). Estimating Peer effects in Swedish High School using School, Teacher and Student Fixed Effects (Economics of Education Review, 28, 329-336)

Wicker, H.-R.; Fibbi, R. \& Haug, W. (2003). Migration und die Schweiz. Zürich: Seismo 
Table 1: Descriptive Statistics. PISA score in reading by immigrant definition

\begin{tabular}{|c|c|c|c|c|}
\hline & \multicolumn{2}{|c|}{ PISA score 2000} & \multicolumn{2}{|c|}{ PISA score 2009} \\
\hline & Mean & Std. error & Mean & Std. error \\
\hline \multicolumn{5}{|l|}{ Definition 1} \\
\hline Immigrants & 469.76 & 2.06 & 491.82 & 1.2 \\
\hline Others & 518.86 & 1.28 & 520.6 & 0.9 \\
\hline \multicolumn{5}{|l|}{ Definition 2} \\
\hline Immigrants & 445.63 & 2.62 & 471.82 & 1.57 \\
\hline Others & 517.41 & 1.17 & 520.17 & 0.79 \\
\hline \multicolumn{5}{|l|}{ Definition 3} \\
\hline Immigrants & 423.41 & 3.89 & 466.21 & 2.84 \\
\hline Others & 511.28 & 1.12 & 513.19 & 0.74 \\
\hline \multicolumn{5}{|l|}{ Definition 4} \\
\hline Immigrants & 462.63 & 3.70 & 475.33 & 1.9 \\
\hline Others & 507.31 & 1.18 & 514.98 & 0.77 \\
\hline \multicolumn{5}{|c|}{ Language spoken at home } \\
\hline Foreign language & 443.98 & 2.83 & 469.75 & 1.79 \\
\hline Test language & 515.54 & 1.14 & 516.7 & 0.74 \\
\hline N & 6754 & & 13988 & \\
\hline Total & 502.13 & & 509.53 & \\
\hline
\end{tabular}

Table 2: Individual and school characteristics by immigrant's definition

\begin{tabular}{|c|c|c|c|c|c|c|c|c|c|c|c|}
\hline & \multicolumn{2}{|c|}{ Definition 1} & \multicolumn{2}{|c|}{ Definition 2} & \multicolumn{2}{|c|}{ Definition 3} & \multicolumn{2}{|c|}{ Definition 4} & \multicolumn{2}{|c|}{ Natives* } & \multirow[b]{2}{*}{ All } \\
\hline & Mean & $\begin{array}{l}\text { Std. } \\
\text { error }\end{array}$ & Mean & $\begin{array}{l}\text { Std. } \\
\text { error }\end{array}$ & Mean & $\begin{array}{l}\text { Std. } \\
\text { error }\end{array}$ & Mean & $\begin{array}{l}\text { Std. } \\
\text { error }\end{array}$ & Mean & $\begin{array}{l}\text { Std. } \\
\text { error }\end{array}$ & \\
\hline \multicolumn{12}{|l|}{ Year 2000} \\
\hline \multicolumn{12}{|l|}{ Individual characteristics } \\
\hline Reading score & 469.76 & 2.06 & 445.63 & 2.62 & 423.41 & 3.89 & 462.63 & 3.70 & 518.86 & 1.28 & 502.13 \\
\hline Parents' education: tertiary & 0.34 & 0.01 & 0.27 & 0.01 & 0.25 & 0.02 & 0.26 & 0.02 & 0.38 & 0.01 & 0.37 \\
\hline Parents' education: compulsory & 0.14 & 0.01 & 0.19 & 0.01 & 0.21 & 0.02 & 0.2 & 0.02 & 0.06 & 0.003 & 0.08 \\
\hline Foreign language & 0.49 & 0.01 & 0.69 & 0.01 & 0.8 & 0.02 & 0.65 & 0.02 & 0.03 & 0.003 & 0.19 \\
\hline Socio-economic index & 45.69 & 0.34 & 42.11 & 0.42 & 39.23 & 0.6 & 43.34 & 0.61 & 50.18 & 0.23 & 48.65 \\
\hline \multicolumn{12}{|l|}{ School characteristics } \\
\hline Proportion of foreign language speakers & 0.24 & 0.003 & 0.27 & 0.004 & 0.28 & 0.01 & 0.28 & 0.01 & 0.15 & 0.002 & 0.18 \\
\hline Number of students & 519.62 & 8.25 & 529.35 & 10.69 & 522.7 & 15.04 & 536.72 & 17.06 & 447.44 & 5.16 & 472.02 \\
\hline $\mathrm{N}$ & 2337 & & 1424 & & 678 & & 604 & & 4417 & & 6754 \\
\hline \multicolumn{12}{|l|}{ Year 2009} \\
\hline \multicolumn{12}{|l|}{ Individual characteristics } \\
\hline Reading score & 491.82 & 1.2 & 471.82 & 1.57 & 466.21 & 2.84 & 475.33 & 1.91 & 520.6 & 0.9 & 509.53 \\
\hline Parents' education: tertiary & 0.52 & 0.01 & 0.43 & 0.01 & 0.45 & 0.02 & 0.42 & 0.01 & 0.57 & 0.01 & 0.55 \\
\hline Parents' education: compulsory & 0.07 & 0.003 & 0.11 & 0.01 & 0.10 & 0.01 & 0.12 & 0.01 & 0.01 & 0.001 & 0.04 \\
\hline Foreign language & 0.38 & 0.01 & 0.6 & 0.01 & 0.66 & 0.01 & 0.58 & 0.01 & 0.02 & 0.002 & 0.16 \\
\hline Socio-economic index & 48.52 & 0.22 & 44.07 & 0.28 & 44.34 & 0.54 & 43.73 & 0.34 & 52.67 & 0.17 & 51.08 \\
\hline \multicolumn{12}{|l|}{ School characteristics } \\
\hline Proportion of foreign language speakers & 0.18 & 0.002 & 0.2 & 0.002 & 0.2 & 0.003 & 0.2 & 0.003 & 0.12 & 0.001 & 0.14 \\
\hline Number of students & 545.49 & 4.78 & 552.10 & 6.36 & 529.56 & 11.24 & 563.35 & 7.88 & 486.54 & 3.92 & 509.21 \\
\hline $\mathrm{N}$ & 5631 & & 3216 & & 1095 & & 2031 & & 8357 & & 13988 \\
\hline
\end{tabular}

* Natives includes all children who have both parents Swiss-born 
Table 3: Oaxaca Decomposition of immigrants vs. natives

\begin{tabular}{|c|c|c|c|c|c|c|c|c|}
\hline \multirow{3}{*}{ (A) ${ }^{1}$} & \multicolumn{4}{|c|}{ Year 2000} & \multicolumn{4}{|c|}{ Year 2009} \\
\hline & \multicolumn{2}{|c|}{$\begin{array}{c}\text { Regression OLS } \\
\text { Natives }\end{array}$} & \multicolumn{2}{|c|}{$\begin{array}{l}\text { Regression OLS } \\
\text { immigrants }\end{array}$} & \multicolumn{2}{|c|}{$\begin{array}{l}\text { Regression OLS } \\
\text { Natives }\end{array}$} & \multicolumn{2}{|c|}{$\begin{array}{l}\text { Regression OLS } \\
\text { immigrants }\end{array}$} \\
\hline & Coefficient & Std. errors ${ }^{2}$ & Coefficient & Std. errors ${ }^{2}$ & Coefficient & Std. errors ${ }^{2}$ & Coefficient & Std. errors ${ }^{2}$ \\
\hline Socioeconomic Index & 0.99 & $0.072^{* *}$ & 0.84 & $0.26^{* *}$ & 0.86 & $0.02^{* *}$ & 1.34 & $0.07^{* *}$ \\
\hline Parents' education: tertiary & -0.5 & 2.16 & 9.2 & 8.92 & 6.80 & $0.64^{* *}$ & -11.03 & $2.42^{* *}$ \\
\hline Parents' education: compulsory & -29.68 & $3.91^{* *}$ & -21.68 & $8.13^{* *}$ & -20.31 & $1.76^{* *}$ & -2.9 & 3.51 \\
\hline Less than 100 books at home & -31.07 & $2.03^{* *}$ & -47.88 & $9^{* *}$ & -30.58 & $0.63^{* *}$ & -37.18 & $2.9^{* *}$ \\
\hline Foreign language & -26.62 & $3.11^{* *}$ & -7.79 & 8.28 & -21.47 & $0.97^{* *}$ & -9.31 & $2.32^{* *}$ \\
\hline $\begin{array}{l}\text { Proportion of foreign language speakers } \\
\text { at school: } 20-40 \%\end{array}$ & -27.03 & $2.5^{* *}$ & -35.76 & $7.85^{* *}$ & -28.16 & $0.78^{* *}$ & -32.01 & 2.33 \\
\hline $\begin{array}{l}\text { Proportion of foreign language speakers } \\
\text { at school: }>40 \%\end{array}$ & -65.09 & $3.73^{* *}$ & -78.67 & $8.75^{* *}$ & -35.02 & $2.23^{* *}$ & -64.6 & $4.57^{* *}$ \\
\hline Constant & 845.79 & $28.20^{* *}$ & 806.46 & $76.94^{* *}$ & 777.66 & $8.59^{* *}$ & 939.13 & 28.99 \\
\hline R2 & 0.26 & & 0.33 & & 0.26 & & 0.39 & \\
\hline N & 6076 & & 678 & & 12893 & & 1095 & \\
\hline \multicolumn{9}{|l|}{ (B) Decomposition } \\
\hline Total difference & 88.45 & $100 \%$ & & & 46.83 & $100 \%$ & & \\
\hline Explained & 66.36 & $75 \%$ & & & 34.74 & $74 \%$ & & \\
\hline Unexplained & 22.09 & $25 \%$ & & & 12.09 & $26 \%$ & & \\
\hline
\end{tabular}

** $\quad$ significant at $1 \%$ level, *significant at $5 \%$ level, + significant at $10 \%$ level

1 We also control for gender, age, family structure, siblings, and school characteristics such as community type, number of students and whether the school is private or public

2 All standard errors account for errors's correlations at the school level 
Table 4: Oaxaca decomposition of the score gap between 2000 and 2009 for first generation immigrants

\begin{tabular}{|c|c|c|c|c|}
\hline \multirow[t]{2}{*}{ (A) } & \multicolumn{2}{|c|}{ Regression OLS 2009} & \multicolumn{2}{|c|}{ Regression OLS 2000} \\
\hline & Coefficient & Std. error & Coefficient & Std. error \\
\hline Female & 30.38 & $2.15^{* *}$ & 8.34 & 6.66 \\
\hline Age & -26.74 & $1.64^{* *}$ & -9.69 & $5.24+$ \\
\hline SEI & 1.40 & $0.08^{* *}$ & 0.89 & $0.28^{* *}$ \\
\hline Parents'education: tertiary & -6.86 & $2.57^{* *}$ & 14.86 & 9.55 \\
\hline Parents' education: compulsory & 0.24 & 3.69 & -16.36 & $8.71+$ \\
\hline Family structure: single & -3.78 & 3.51 & -20.61 & $10.82+$ \\
\hline Family Structure: mixed & -34.71 & $11.5^{* *}$ & 12.97 & 15.05 \\
\hline Siblings (yes) & -5.89 & $3.19+$ & -53.00 & $12.78^{* *}$ \\
\hline Less than 100 books at home & -50.82 & $3.00^{* *}$ & -52.36 & $9.48^{* *}$ \\
\hline Foreign language at home & -17.18 & $2.41^{* *}$ & -14.28 & 8.91 \\
\hline Age at immigration & 0.91 & $0.22^{* *}$ & -3.05 & $0.88^{* *}$ \\
\hline Latin Switzerland & -7.001 & $2.36^{* *}$ & 20.98 & $8.07^{* *}$ \\
\hline Constant & 871.06 & $27.02^{* *}$ & 658.04 & $84.78^{* *}$ \\
\hline R2 & 0.32 & & 0.25 & \\
\hline N & 1095 & & 678 & \\
\hline \multicolumn{5}{|l|}{ (B) Decomposition } \\
\hline Total gap & 42.53 & $100 \%$ & & \\
\hline Explained & 16.79 & $40 \%$ & & \\
\hline \multirow[t]{3}{*}{ Unexplained } & 25.74 & $60 \%$ & & \\
\hline & \multicolumn{2}{|c|}{ Explained } & \multicolumn{2}{|c|}{ Unexplained } \\
\hline & Coefficient & Std. error & Coefficient & Std. error \\
\hline Female & 1.99 & $1.07+$ & 10.23 & $4.82^{*}$ \\
\hline Age & 3.03 & $1.76+$ & -274.15 & $136.82^{*}$ \\
\hline SEI & 7.35 & $2.16^{* *}$ & 19.89 & 16.53 \\
\hline Parents' education: tertiary & -1.4 & 1.72 & -5.3 & 3.3 \\
\hline Parents' education: compulsory & -0.02 & 1.13 & 3.4 & 3.21 \\
\hline Family structure: single & 0.01 & 0.07 & 1.87 & 1.92 \\
\hline Family Structure: mixed & 1.53 & 1.49 & -2.53 & 2.13 \\
\hline Siblings (yes) & 0.38 & 0.58 & 43.56 & $19.13^{*}$ \\
\hline Less than 100 books at home & 2.84 & $1.62+$ & 1.24 & 12.51 \\
\hline Foreign language at home & 2.31 & $1.12^{*}$ & -2.32 & 9.78 \\
\hline Age at immigration & -0.67 & 0.61 & 24.81 & $9.47^{* *}$ \\
\hline Latin Switzerland & -0.57 & 0.78 & -7.99 & $4.3^{+}$ \\
\hline Constant & & & 213.02 & 139.53 \\
\hline
\end{tabular}

** significant at $1 \%$ level, * significant at $5 \%$ level, + significant at $10 \%$ level 
Table 5: Oaxaca decomposition of the score gap between 2000 and 2009 for first generation immigrants including controls for country of origin

\begin{tabular}{|c|c|c|c|c|}
\hline \multirow[t]{2}{*}{ (A) } & \multicolumn{2}{|c|}{ Regression OLS 2009} & \multicolumn{2}{|c|}{ Regression OLS 2000} \\
\hline & Coefficient & Std. error & Coefficient & Std. error \\
\hline Female & 33.46 & $2.12^{* *}$ & 7.49 & 6.68 \\
\hline Age & -23.22 & $1.63^{* *}$ & -9.00 & $5.22+$ \\
\hline SEI & 1.24 & $0.08^{* *}$ & 0.74 & $0.28^{* *}$ \\
\hline Parents' education: tertiary & -5.45 & $2.57^{*}$ & 15.87 & $9.64+$ \\
\hline Parents' education: compulsory & 2.92 & 3.65 & -17.72 & $8.86^{*}$ \\
\hline Family structure: single & -6.85 & $3.49^{*}$ & -22.57 & $11.01^{* *}$ \\
\hline Family Structure: mixed & -30.57 & $11.33^{* *}$ & 4.57 & 15.46 \\
\hline Siblings (yes) & -3.68 & 3.17 & -46.75 & $12.90^{* *}$ \\
\hline Less than 100 books at home & -47.62 & $2.98^{* *}$ & -46.01 & $9.86^{* *}$ \\
\hline Foreign language at home & 3.03 & 2.8 & -10.11 & 9.29 \\
\hline Age at immigration & -0.15 & 0.24 & -2.80 & $0.89^{* *}$ \\
\hline Latin Switzerland & 1.53 & 2.54 & 13.15 & 8.66 \\
\hline Country of origin1: Germany, France, Austria, Belgium & 51.2 & $4.10^{* *}$ & 20.36 & 19.36 \\
\hline Country of origin: Italy, Spain, Portugal & -3.31 & 3.54 & 5.21 & 12.16 \\
\hline Country of origin: Albania, Kosovo, Ex Yugoslavia & -12.18 & $3.15^{* *}$ & -22.06 & $10.75^{*}$ \\
\hline Country of origin: Turkey & 5.72 & 7.19 & -25.84 & $15.16+$ \\
\hline Constant & 802.67 & $27.22^{* *}$ & 651.34 & $84.71^{* *}$ \\
\hline R2 & 0.35 & & 0.26 & \\
\hline N & 1095 & & 678 & \\
\hline
\end{tabular}

(B) Decomposition

\begin{tabular}{|c|c|c|c|c|}
\hline Total gap & 42.53 & $100 \%$ & & \\
\hline Explained & 20.32 & $48 \%$ & & \\
\hline \multirow[t]{3}{*}{ Unexplained } & 22.21 & $52 \%$ & & \\
\hline & \multicolumn{2}{|c|}{ Explained } & \multicolumn{2}{|c|}{ Unexplained } \\
\hline & Coefficient & Std. error & Coefficient & Std. error \\
\hline Female & 2.19 & $1.16+$ & 12.06 & $4.8^{*}$ \\
\hline Age & 2.64 & $1.55^{+}$ & -228.83 & $133.30+$ \\
\hline SEI & 6.51 & $1.99^{* *}$ & 19.45 & 16.94 \\
\hline Parents 'education: tertiary & -1.11 & 1.68 & -5.20 & 3.30 \\
\hline Parents' education: compulsory & -0.29 & 1.09 & 4.23 & 3.11 \\
\hline Family structure: single & 0.02 & 0.12 & 1.75 & 2.03 \\
\hline Family Structure: mixed & 1.35 & 1.49 & -1.87 & 2.15 \\
\hline Siblings (yes) & 0.24 & 0.58 & 39.83 & $18.86^{*}$ \\
\hline Less than 100 books at home & 2.66 & $1.53^{+}$ & -1.30 & 12.45 \\
\hline Foreign language at home & -0.41 & 0.94 & 10.50 & 9.56 \\
\hline Age at immigration & 0.11 & 0.61 & 16.63 & $9.48+$ \\
\hline Latin Switzerland & 0.12 & 0.67 & -3.32 & 4.42 \\
\hline Country of origin1: Germany, France, Austria, Belgium & 4.63 & $1.55^{* *}$ & 1.32 & 1.12 \\
\hline Country of origin: Italy, Spain, Portugal & 0.14 & 0.42 & -1.75 & 3.62 \\
\hline Country of origin: Albania, Kosovo, Ex Yugoslavia & 1.83 & 1.57 & 4.94 & 9.09 \\
\hline Country of origin: Turkey & -0.30 & 1.07 & 2.44 & 2.14 \\
\hline Constant & & & 151.33 & 137.96 \\
\hline
\end{tabular}

** significant at $1 \%$ level, ${ }^{*}$ significant at $5 \%$ level, + significant at $10 \%$ level

1 Reference: other 
Table 6: School composition: Proportion of foreign language speakers at school

\begin{tabular}{|c|c|c|c|}
\hline \multirow[t]{2}{*}{ (A) } & \multicolumn{3}{|c|}{2000} \\
\hline & $<20 \%$ & $20-40 \%$ & $>40 \%$ \\
\hline First generation (Definition 3) & 0.43 & 0.32 & 0.25 \\
\hline Second generation (Definition 4) & 0.40 & 0.34 & 0.26 \\
\hline Natives $^{1}$ & 0.75 & 0.18 & 0.07 \\
\hline Total & 0.67 & 0.22 & 0.11 \\
\hline (B) & & 2009 & \\
\hline First generation (Definition 3) & 0.56 & 0.38 & 0.07 \\
\hline Second generation (Definition 4) & 0.56 & 0.39 & 0.06 \\
\hline Natives & 0.84 & 0.15 & 0.01 \\
\hline Total & 0.76 & 0.22 & 0.02 \\
\hline
\end{tabular}

1 Natives includes all children whose parents were both born in Switzerland. 
Table 7: Oaxaca decomposition of the score gap between 2000 and 2009 for first generation immigrants including controls for school characteristics

\begin{tabular}{|c|c|c|c|c|}
\hline \multirow[t]{2}{*}{ (A) } & \multicolumn{2}{|c|}{ Regression OLS 2009} & \multicolumn{2}{|c|}{ Regression OLS 2000} \\
\hline & Coefficient & Std. error & Coefficient & Std. error \\
\hline Female & 30.38 & $2.04^{* *}$ & 5.70 & 6.32 \\
\hline Age & -24.93 & $1.57^{* *}$ & -9.77 & $4.95^{*}$ \\
\hline SEI & 1.16 & $0.08^{* *}$ & 0.58 & $0.27^{*}$ \\
\hline Parents 'education: tertiary & -10.23 & $2.46^{* *}$ & 12.94 & 9.11 \\
\hline Parents' education: compulsory & -0.46 & 3.49 & -23.51 & $8.37^{* *}$ \\
\hline Family structure: single & -9.24 & $3.33^{* *}$ & -15.74 & 10.35 \\
\hline Family Structure: mixed & -29.47 & $10.86^{* *}$ & 9.47 & 14.65 \\
\hline Siblings (yes) & -9.19 & $3.04^{* *}$ & -46.13 & $12.19^{* *}$ \\
\hline Less than 100 books at home & -35.71 & $2.90^{* *}$ & -41.13 & $9.38^{* *}$ \\
\hline Foreign language at home & 9.57 & $2.71^{* *}$ & 0.59 & 8.80 \\
\hline Age at immigration & -0.53 & $0.23^{*}$ & -2.92 & $0.84^{* *}$ \\
\hline Latin Switzerland & -1.89 & 2.58 & -4.56 & 8.47 \\
\hline Country of origin1: Germany, France, Austria, Belgium & 43.11 & $3.96^{* *}$ & 16.96 & 18.25 \\
\hline Country of origin: Italy, Spain, Portugal & -5.87 & $3.40+$ & 0.09 & 11.46 \\
\hline Country of origin: Albania, Kosovo, Ex Yugoslavia & -13.59 & $3.03^{* *}$ & -24.87 & $10.38^{*}$ \\
\hline Country of origin: Turkey & 7.65 & 6.86 & -23.62 & $14.24^{+}$ \\
\hline Public & -67.28 & $11.82^{* *}$ & -18.78 & 23.35 \\
\hline School size & 0.04 & $0.003^{* *}$ & 0.01 & 0.01 \\
\hline Proportion of foreign language speakers $20-40 \%$ & -29.04 & $2.34^{* *}$ & -36.20 & $7.93^{* *}$ \\
\hline Proportion of foreign language speakers $>40 \%$ & -63.48 & $4.53^{* *}$ & -80.27 & $8.79^{* *}$ \\
\hline Constant & 899.47 & $29.33^{* *}$ & 717.56 & $81.93^{* *}$ \\
\hline R2 & 0.41 & & 0.36 & \\
\hline N & 1095 & & 678 & \\
\hline
\end{tabular}

(B) Decomposition

\begin{tabular}{|c|c|c|c|c|}
\hline Total gap & 42.53 & $100 \%$ & & \\
\hline Explained & 28.91 & $68 \%$ & & \\
\hline \multirow[t]{3}{*}{ Unexplained } & 13.61 & $32 \%$ & & \\
\hline & \multicolumn{2}{|c|}{ Explained } & \multicolumn{2}{|c|}{ Unexplained } \\
\hline & Coefficient & Std. error & Coefficient & Std. error \\
\hline Female & 1.99 & $1.06+$ & 11.46 & $4.16^{* *}$ \\
\hline Age & 2.83 & $1.64^{+}$ & -243.76 & $124.86^{*}$ \\
\hline SEI & 6.09 & $1.86^{* *}$ & 22.89 & 15.62 \\
\hline Parents 'education: tertiary & -2.09 & 1.59 & -5.65 & $3.10+$ \\
\hline Parents' education: compulsory & 0.05 & 1.09 & 4.72 & 3.09 \\
\hline Family structure: single & 0.03 & 0.17 & 0.72 & 1.85 \\
\hline Family Structure: mixed & 1.30 & 1.34 & -2.07 & 1.88 \\
\hline Siblings (yes) & 0.59 & 0.56 & 34.16 & $17.72^{*}$ \\
\hline Less than 100 books at home & 2.00 & $1.18+$ & 4.38 & 11.98 \\
\hline Foreign language at home & -1.29 & 0.98 & 7.17 & 9.13 \\
\hline Age at immigration & 0.39 & 0.60 & 14.96 & $8.79+$ \\
\hline Latin Switzerland & -0.15 & 0.62 & 0.76 & 3.72 \\
\hline Country of origin1: Germany, France, Austria, Belgium & 3.90 & $1.39^{* *}$ & 1.12 & 1.05 \\
\hline Country of origin: Italy, Spain, Portugal & 0.24 & 0.42 & -1.22 & 3.29 \\
\hline Country of origin: Albania, Kosovo, Ex Yugoslavia & 2.04 & 1.52 & 5.64 & 8.18 \\
\hline Country of origin: Turkey & -0.41 & 0.98 & 2.41 & 1.97 \\
\hline Public & -0.73 & 0.74 & -47.61 & 36.87 \\
\hline School size & 0.25 & 2.69 & 17.25 & $9.79+$ \\
\hline Proportion of foreign language speakers $20-40 \%$ & -1.42 & 1.90 & 2.34 & 4.39 \\
\hline Proportion of foreign language speakers $>40 \%$ & 13.44 & $4.58^{* *}$ & 4.62 & 4.66 \\
\hline Constant & & & 181.91 & 132.57 \\
\hline
\end{tabular}

** $\quad$ significant at $1 \%$ level, * significant at $5 \%$ level, + significant at $10 \%$ level

1 Reference: other

2 We also control for the size of the community where the school is located 
Table 8: Oaxaca decomposition results by immigrants' definition

\begin{tabular}{|c|c|c|c|}
\hline Definition & Total $^{1}$ & Explained & Unexplained \\
\hline 1 & 22.06 & $56 \%$ & $44 \%$ \\
\hline 2 & 26.19 & $52 \%$ & $48 \%$ \\
\hline 3 & 42.53 & $68 \%$ & $32 \%$ \\
\hline 4 & 13.77 & $10 \%$ & $90 \%$ \\
\hline
\end{tabular}

1 Results based on regressions using the specification from Table 7 